\title{
Jak se kreslí (neexistující) zlo
}

\section{How to draw (non-existent) evil}

\author{
Josef Petrželka
}

Nejdůležitějším slovem v nadpise je „kreslí“, protože v hlavní roli mé úvahy je obrázek. Ano, obrázek zla. Jeden z mnoha obrázků Michala Peichla, které vytvořil pro mé kurzy dějin nejstarší filosofie. Hraje hlavní roli, protože zvláštním způsobem propojuje dva odlišné přístupy - přístup filosofický, konceptuální a přístup umělecký, tvưrčí. Představím nejprve přístup filosofický a pak nás právě obrázek přivede $\mathrm{k}$ tomu přístupu tvưrčímu.

Obrázek zla? Čtenáře asi napadnou desítky různých a barvitých vizuálních podob: války, vraždy, četné nemoci a tělesné deformace, př́rodní katastrofy - to by to pro kreslíre mělo být jednoduché. Ano, pokud ovšem nedostane za úkol znázornit specifickou filosofickou koncepci zla, která se objevuje v některých monistických systémech. Abych byl konkrétní, půjde o novoplatónskou a také Augustinovu koncepci zla (či zlé vůle). Vlastně je to koncepce jednoduchá, protože podle ní zlo neexistuje. Jak to?

Už jsem zmínil, že se jedná o monistické systémy, v nichž tedy existuje pouze jeden jediný princip - novoplatónské Jedno či Augustinův trojjediný Bůh. Z hlediska úvahy o zlu je zcela zásadní skutečnost, že tento princip je v obou systémech také absolutním dobrem a zároveň zdrojem dobra. Detaily, příp. rozdíly mezi oběma systémy a jejich principy můžeme ponechat stranou, ted' to jen domysleme: Je zde jediný princip, který je v nějakém ohledu počátkem všeho, co existuje, a tento princip je zároveň dobrý. Pak ovšem vše, co z něj pochází, musí mít nutně podíl na jeho dobrosti! A protože neexistuje žádný rovnocenný protivný princip (to bychom totiž už byli v dualistickém systému), pak ani neexistuje nic, co by mohlo být příčinou či zdrojem opaku 
dobra, jímž je intuitivně vzato právě to naše hledané zlo. Můžeme tedy vůbec říci, že nějaké zlo existuje?!

$\mathrm{Ne}$, striktně vzato to říci nemůžeme. Nic zlého neexistuje. Jenže - málokdo jsme natolik přesvědčeným optimistou, že bychom se ze všeho těšili a úplně o všem tvrdili, že je to dobré, a že bychom skutečně vůbec nic nenazvali zlem. Ale co to vlastně máme - jsme-li monisty a je-li náš jediný princip absolutním dobrem - na mysli, když připouštíme, že některé věci, jevy či děje jsou zlé?

Novoplatónikové si s touto otázkou poradili velmi elegantně:

Zlo tohoto světa pochází z potřeby, zbavenosti, nedostatku a je stavem ubohé látky a toho, co bylo látce připodobněno. ${ }^{1}$

... čemu nic nenáleží, a co tedy je ve stavu nedostatku - a zvláště co je podstatným způsobem nedostatkem - to je nutně zlem. Látka totiž není nedostatkem bohatství, nýbrž nedostatkem rozumnosti, nedostatkem ctnosti, krásy, síly, formy, tvaru, kvality. Jak by to mohlo nebýt nerozlišitelné? Jak nebýt naprosto ošklivé? Jak nebýt naprosto zlé??

Ano, sice platí, že neexistuje žádný zlý či zlovolný a zlopůsobící princip ani zlo jako nějaká substance či vlastnost, nýbrž existuje pouze dobro a vlastnost být dobrý. Jenže výše jsme řekli, že ten jediný princip monistických systémů je dobrem absolutním. $Z$ toho asi nutně plyne (a to s velmi silnou nutností), že cokoli jiného, cokoli mimo principu samotného, bude sice také dobré, ale prostě méně dobré než samotný princip. A zde se otevírá prostor pro označení „zlo“. Zvláště když půjdeme stále dále od našeho absolutně dobrého principu (novoplatónský i Augustinův systém jsou výrazně hierarchické, obsahují více ontologických rovin) a když dojdeme nejdále, kam až to jde. U novoplatóniků se octneme u látky o sobě (lze-li vypovědět „o sobě“ o tom, co nemá ani zbla rozumnosti, ctnosti, krásy, síly, formy, tvaru atd.).

Augustinus s novoplatónskou koncepcí zla v zásadě souhlasí, ale - naštěstí - podává následující přirovnání (v mírně jiném kontextu, když se ptá po příčině zlé vůle):

Tedy at působící příčinu zlé vůle nikdo nehledá; není totiž účinná (efficiens), nýbrž deficientní (deficiens), nebot’ ani ta zlá vůle není účinným působením, ale defek-

1 PLÓTÍNOS. Enneady V 9, 10, 18-20.

2 PLÓTÍNOS. Enneady II 4, 16, 19-24 (volně s využitím anglického překladu S. MacKenny a B. S. Page). 
tem. Nebot’ odpadnutí od toho, který svrchovaně jest, k tomu, co jest méně, to právě znamená začít mít zlou vůli. Chtít potom nalézti přičiny těchto odpadnutí (defectiones), které nejsou působící, jak jsem řekl, ale deficientní, to by bylo něco takového, jako kdyby někdo chtěl viděti tmu nebo slyšeti ticho - věci to, jež jsou nám přesto obě známy, a to jedna výhradně skrze oči, druhá výhradně skrze uši, ovšem ne ve své podobě, ale ve zbavenosti podoby. ${ }^{3}$

Proč to „naštěsti““? Totiž, z toho Plótínova popisu nám vycházelo, že zlo je zcela „nerozlišitelné“, chybí mu jakákoli určitost - a jak by měl kreslír něco takového zobrazit?! Augustinus však předkládá záměrně a explicitně právě přirovnání z oblasti smyslového vnímání a jedno z nich spadá pod vnímání zrakové (tma je jistě zrakový vjem). Můžeme tedy kreslit!

Ovšem tím problémy se ztvárněním zla nekončí, pouze jsme je přesunuli z filosofa na kreslíře. Uvažujme - co je „tma“? Tma je charakteristika místa, kde nic nevidíme, ač máme otevřené (a zdravé) oči. Nevidíme žádné barvy, protože tam není žádné světlo (nejsou tam žádné fotony s vlnovou délkou v jistém rozmezí, at se vyjadřujeme moderně a exaktně), a tedy vlastně nemáme žádný vjem, žádné světlo na náš zrak nepůsobí, jak tomu rozumí i Augustinus. Ale jak to má kreslír znázornit? Jak to udělal Michal Peichl, vidíte na následující stránce.

Z hlediska kreslíre či malíře je to totiž tak trochu naopak. Protože se většinou maluje či kreslí na bílou plochu (černá tabule a bílá křída jsou spíše výjimkou), jsme uvyklí vnímat jako prázdné, tj. barvou nepokryté, to místo, kde zůstává bílé plátno nebo tužkou či barvou nedotčený bílý papír. Tam je tedy z pohledu tvưrce nedostatek - absence barvy i absence tvưrčí činnosti. Chce-li však tradiční umělec zapřičinit naopak vjem černé tmy, musí to místo, které má být černé, nikoli ponechat prázdné a v úplném nedostatku, nýbrž naopak velmi intenzivně - inu, začernit. To jde snadno, když se vezme široký štětec (a máme dost černé barvy), podstatně náročnější to je při práci s tenoučkým perem. Michal Peichl svou práci s černým perem o tlouštce $0,1 \mathrm{~mm}$ popisuje precizně, ale zároveň až poeticky:

Zde u obrázku bylo navíc jasné, že čáry půjdou jedním směrem. Chce to tedy hlavně pevnou podložku a pak už jen pevnou ruku a linku v ní. Z digitální malby jsem zvyklý na to, že mohu kdykoliv stisknout CTRL + Z a vrátit se zpět nebo pohnout s částí obrazu. Ale pero se vpije, je to bud' 1 , nebo 0 , konečná. Poté, co jsem usedl

3 AUGUSTINUS AURELIUS. O obci Boži XII 7, Praha: Karolinum 2007 (upravený překlad J. Novákové). 


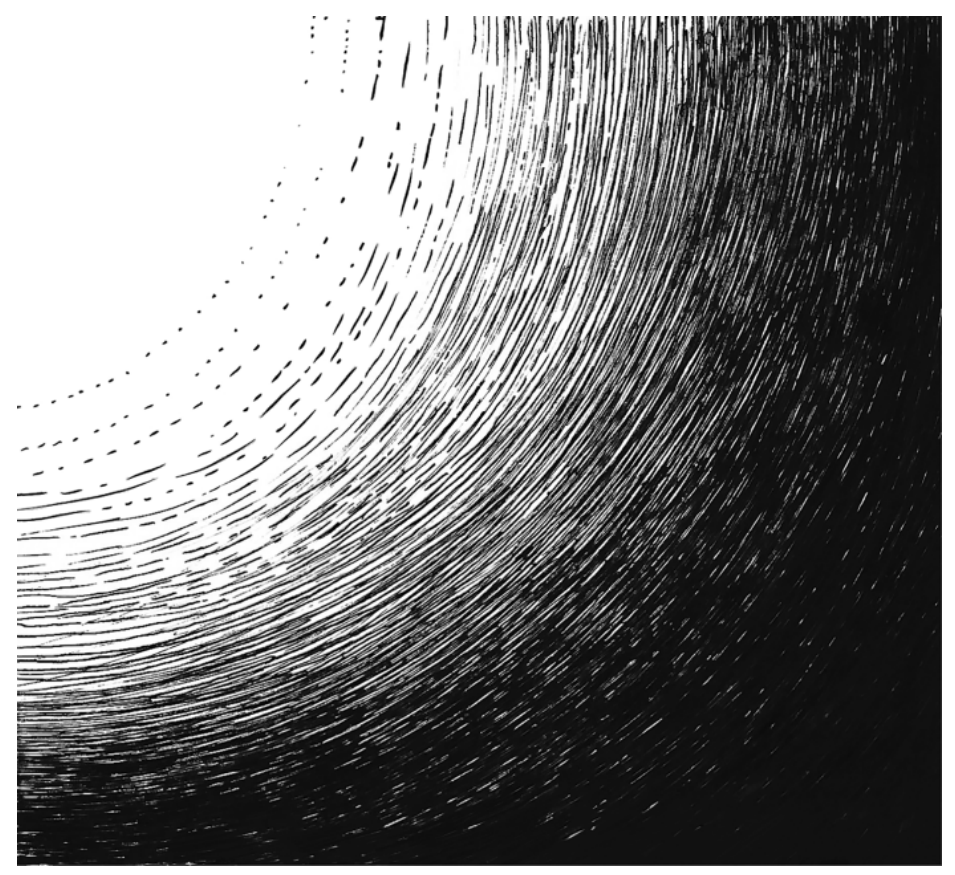

Zlo jako nedostatek dobra, Michal Peichl, 2016

do vhodné pozice, jsem se jal kreslit pohybem stěrače automobilu. Plná černá plocha vznikla poctivě postaru jemnými tahy, kupenými na sebe. U obrázku jsem tedy strávil nějaký ten čas. Můžete si i všimnout, že některé čáry jsou napojované, protože nejdelší části kruhu nešlo udělat snadno. Toho jsem však využil, abych dodal obrazu jakousi efemérnost, která je vlastní světlu. Dobro tedy nesahá jako průběžný gradient všude stejně daleko, ale má i jisté odchylky, nepravidelný okraj a nepravidelnou míru. ${ }^{4}$

Tolik k cestě od filosofického zadání k uměleckému ztvárnění. Ale obrázek a Michalův popis ted' vrací dva myšlenkové podněty. Totiž, možná by se jich našlo více, ale mne napadají jen tyto dva...

Jeden z nich se týká onoho nestejnoměrného dosahu světla/dobra. Někde se nachází bílá i za černou čárou, jako by tedy první instance nižší úrovně dobra (tj. první instance „zla“) neodstínila světlo absolutně a definitivně, nýbrž aspoň částečně je propouští, nebo dokonce distribuuje dále od zdroje. Tento podnět vede k otázce, zda úrovně skutečnosti nižší než např. novoplatónské

4 Michal Peichl, e-mailová komunikace, 12. 9. 2019. 
Jedno/Dobro - tj. Duch a Duše - a charakterizované nutně menší jednotou a také méně dobré už vlastně obsahují jakési stř́ípky zla (byt dobro zatím jednoznačně převažuje) a zda světlo/dobro odčerpávají pro sebe a vrhají stín na vzdálenější úrovně, nebo zda by byl novoplatónský výklad naladěn optimističtěji a zdůrazňoval spíše zprostředkování světla vzdálenějším úrovním skrze ty úrovně Jednu bližší. Těžká otázka, přenechám ji raději specialistům.

Druhý podnět podává způsob kresby. V Antické filosofii v obrázcích Michal uvádí, že nejprve zkoušel zachytit jakoby paprsky světla pomocí čar či struktur směřujících z toho bílého rohu do černého (technicky vzato se to dálo opět opačně, byly to černé struktury směřující z černého rohu do bílého). Ale ani po několika pokusech to nevypadalo dobře, proto posléze prrišel na variantu „stěračových čtvrtkruhů“. Obrázek tedy nezachytává směr šíření fotonů - ale když přjdeme od částicového k vlnovému uchopení světla jakožto elektromagnetického záření, najednou to sedí! Elektromagnetické pole se totiž vlní ve dvou vzájemně kolmých rovinách (elektrická vs. magnetická složka), které jsou navíc obě kolmé na směr šíření. Ovšem tento podnět či postř̌eh už nemůže patřit novoplatónikům či Augustinovi, nýbrž až moderní době znalé fyzikálních polí a jejich šíření.

A tento podnět snad také aspoň trochu podporuje tvrzení Johna Barrowa v knize Vesmír plný umění, ${ }^{5}$ že umění a věda (v tomto kontextu můžeme filosofii položit vedle vědy) občas jdou různými cestami ke stejným výsledkům.

Je to právě ta svébytnost tvorby, nutnost odlišného pohledu a pak také ta zpětná inspirace, co se mi na tomto obrázku líbí a kvưli čemu mám tento Michalův obrázek velmi rád.

\section{PhDr. Josef Petrželka, Ph.D.}

Katedra filozofie, Filozofická fakulta, Masarykova univerzita Arna Nováka 1, 60200 Brno, Česká republika josef@phil.muni.cz 
